IJ§ER

ISSN: $2149-5939$
International Journal of Social Sciences and Education Research

Online, http://dergipark.gov.tr/ijsser

Volume: 3(3), 2017

\title{
Bir Žižekci okuma: n11.com, Akbank \& Sinpaş GYO reklam filmlerinin söylemsel analizi ${ }^{1}$
}

\author{
A Žižekian reading: Discourse analysis of n11.com, Akbank \& Sinpaş GYO advertisements
}

\author{
Erhan Özcan ${ }^{2}$
}

\begin{abstract}
Received Date: 02 / 02 / 2017
Accepted Date: 03 / $06 / 2017$

$\ddot{O} z$

Bu çalışmada n11.com, Akbank ve Sinpaş GYO reklam filmleri ünlü Fransız psikanalist ve psikiyatr Jacques Lacan'ın gelişstirdiği yapısalcı psikanalist düşünceyle dirsek teması kuran Žižekci düşünce ve kavram seti eşliğinde ele alınmıştır. Bu bağlamda, ele alınan reklam içeriklerinin çözümlenmesinde Žižekci düşüncenin "artıkkeyif", "obje petit a", "Simgesel", "jouissance", "yamuk bakmak" ve "mekanik israr" benzeri kavramların açıklama gücünden yararlanılmıştır. Bu yolla, konu edilen reklam filmlerinin bilinçdışına seslenme pratikleri somut/popüler örnekler eşliğinde açıklanmıştır. Çalışmanın sonucunda; reklamların tüketici/izleyici öznelerin fantezilerine seslendiği; reklam anlatılarl/imgeleri yoluyla bireylere libidinal enerjilerini tüketim nesnelerine yatırmaları yönünde ikna ve telkinlerde bulunudulduğu görülmüşür. Ele alınan reklamlar sahip oldukları arzu doyurma vaadini bireylerin eksikliklerine başvurarak; onlara, bu eksikliklerini hatırlatarak/anlatarak gerçekleştirmiştir. Reklamlar bireylerin iç dünyalarına kazılı eksiklikleri uyararak bilince çıkarmakta; sundukları nesneler evreniyle bireylere,- bir yanılsama içerisinde- bu eksikliklerini giderebilecekleri çıkış yollarını göstermektedir. Ne var ki ele alınan reklam filmlerinin de gösterdiği üzere, reklam medyası, tüketici/izleyicisine asla tam olarak tatmin edilemeyecek öznel arzularını doyurma vaadi/iddiasında bulunmaktadır.
\end{abstract}

Anahtar sözcükler: Reklam, Artık-keyif, obje petit a, Simgesel, yamuk bakmak, jouissance, mekanik ısrar

\begin{abstract}
This paper drawing on Žižekian thought and its concepts examines n11.com, Akbank ve Sinpaş GYO advertisements in respect to manipulation of desires. It exploits the explanatory power of some of the prominent LacanoŽižekian concepts such as "surplus-enjoyment", "objet petit a", "Symbolic", "jouissance”, "looking awry" and "mechanical insistence". It tries to show how advertisement media interpellates the unconscious in the light of populer commercial content. It argues these commercial media forms mainly target desires of consumers/audiences, and imbue/convince people to spend their libidinal power on consumer products. These commercial content make pledge to satisfy individual desires by advancing on people's lack, and by telling/reminding of them about this lack. These media forms illusionary allude that world of products they exhibit serve people the exit roads by dint of which they can attain their lack. In view of the examined texts, the paper reveals advertisement media purports to satisfy people's desires which can actually never be attained.
\end{abstract}

Keywords: Advertisement, Surplus-enjoyment, objet petit a, Symbolic, looking awry, jouissance, mechanic insistence

\section{Giriş}

Oswald'ın belirttiği gibi tüketici/izleyici öznenin imgeye yönelik arzusunun kültürel temsillerdeki anlam üretimini yöneten kodların baskın olarak düzenlendiği bir çağda yaşıyoruz (2008, s.37). İçinde bulunduğumuz tarihsel uğrakta tüketim faaliyeti; beslenme, giyinme, isınma ve

${ }^{1}$ ICCSER (2017, Roma) 3.Uluslararası Sosyal Bilimler \& Eğitim Araştırmaları Konferansında sözlü bildiri olarak sunulmuştur.

${ }_{2}^{2}$ Arş. Gör. Erhan Özcan, Hacettepe Üniversitesi İletişim Fakültesi, Beytepe Yerleşkesi-Ankara/Türkiye, erhanozc@yandex.com 
Özcan, E. (2017). Bir Žižekci okuma: n11.com, Akbank \& Sinpaş GYO reklam fillmlerinin söylemsel analizi. International Journal of Social Sciences and Education Research, 3(3), 899-913.

barınma gibi temel insan ihtiyaçlarının karşılanmasıyla sınırlı değil elbette. Esasına bakıldığında, insan doğası da bu tip materyal ihtiyaçlarla sınırlanamayacak denli katmanlıdır. Yine bu manada, tüketimin, günümüzde Inglehart'ın "post-materyalist" değerler olarak nitelediği "aidiyet", "haysiyet", "estetik", "entelektüel tatmin" (2008, s.131) ve arzuların doyurulmasıyla ilişkili olduğu söylenebilir. Toplumsal yaşamın modern örgütlenme biçimi olarak günümüz tüketim toplumlarıyla birlikte; diğer pek çok şey yanı sıra "bireylerin içinde yaşadıkları sosyal dünyaya ilişkin deneyimler parçalanarak atomize olmaktadır" (Held'den aktaran Argın, 1992, s.26). Toplumsal yaşamın hemen her alanı fragmanlaşırken; bireylerin tüketime dönük istek ve talepleri de parçalanarak çeşitlenmektedir. Tam da bu nedenle, katmanlaşarak çeşitlenen tüketim alışkanlıklarının yaratılıp yönlendirilmesine, yani eş deyişle, öngörülür/hesaplanabilir hale dönüştürülmesi büyük önem kazanmaktadır. Bu doğrultuda, Featherstone'un gösterdiği gibi arzuların manipüle edilerek yükselişe geçtiği hedonizmin, mahremiyet teşhirciliğinin, narsistik ve benmerkezci kişilik yapılarının geliştirilmesi adeta bir öncelik haline gelmiştir (1996, s. 120-187).

Yeni tüketim edimlerinin/tarzlarının yaratılması ve yönlendirilmesinde bireyin Freud'un dürtülerin düşünce temsillerinin yani iç uyaranların (dürtü vb.) temsillerinin oluştuğu yüzey olarak tanımladığı bilinçdışı (aktaran Tura, 2010, s.67) hedef alınmaktadır. Bilinçdışının hedef alınmasında, toplumsal alana taşıdı ğı çeşitli kültürel mesajlarla kitle iletişim medyasının merkeze oturduğu rahatlıkla ileri sürülebilir. Kitle iletişim medyası içerisinden bakıldığında, ticari bir medya biçimi olarak, temel işlevi öznelerin libidinal enerjilerini tüketim etkinliğine yatırmaları yönünde ikna ve telkinlerde bulunmak olan reklam medyasının kristalize olduğu söylenebilir. Trehan ve Trehan'ın tanımıyla; belirli bir kitleye yönelik olarak hazırlanan ve bu kitlenin belirli biçimlerde eylemde bulunmasını sağlamak üzere bilgilendirme, ikna etme/hatırlatma amacı taşıan reklamlar (2007, s.144), çeşitli türde kültürel kodları toplumsalbilinç yapısına iletir. Bu içerikler eğitici-öğretici olabildikleri gibi, ikna ve telkin edici niteliği bulunan yorum çerçevelerini de içerirler. Bireylere ihtiyaçlarının ve arzularının gerçekte ne olduğu ve ne olması gerektiği, ihtiyaç ve arzularını "hangi yollarla" gerçekleştirebilecekleri noktasında "yardıma koşan" bu simgesel çerçeveler, bir yandan, gündelik maddi ihtiyaçlarımıza etki edip onları belirlemeye çalışırken; Williamson'un belirttiği gibi “arzu” yaratarak olmak istediğimiz kişileri ve/ya sahip olmak istediklerimizi bize gösterirler. Böylelikle, yansıtma işlevi gören reklamlar bireyde "ayna evresi” etkisi yaratarak, imgesel dönemdeki İdeal-Ego'nun yani egonun arzuladığı ideal benliğin kırıntılarından esintiler sunar (2010, s. 64-66). Duygu, düşünce ve imajların canlı/çarpıcı görsel sunumu, hikâyeleştirici bir içsel mantık ve meta-söylem çerçevesiyle anlam bulan reklam anlatıları/imgeleri mekan ve bağlam aşırıdır. Bu içerikler özel ya da kamusal hemen her mekandadır; farklı gündelik yaşam bağlamları içerisinde karşımıza bir anda çıkabilir. Görsel-işitsel veya yazılı, bu ticari medya formlarını ekran başında, radyonun öbür ucunda, dijital ortamda, "bir sayfayı çevirirken, bir köşeyi dönerken, yanımızdan hızla geçerken görüveririz” (Berger, 2014, s.129). Tüketim uğrağında izleyiciyle/dinleyicisyle karşılaşan bu içerikler bireylerde haz ufku üretirken, Baumann'ın ileri sürdüğü gibi öznelere kesintisiz bir heyecan, sönmek bilmeyen bir coşkunluk pompalar. Onları baştan çıkarıcı yeni isteklerle yüz yüze bırakır (1999, s.43). Reklamların bununla yapmak istediği şey çok katmanlıdır: İlkin Berger'in de dediği gibi seyircide içinde bulunduğu yaşamdan bir ölçüde memnun olmadığı duygusunun kamçılanması istenir. Diğer yandan, toplumun yaşamında değil, bireyin kendi öznel yaşamında bir eksiklik olduğunu anımsaması ve duyumsaması hedeflenir (2014, s.142). Son olarak, anlam dünyasını tüketim kültürü ve tüketim rasyonalitesiyle uyumlu olacak şekilde deneyimleyen öznelerin üretilmesi amaçlanır. Reklamlar başta da denildiği gibi bunu belirli bir vaat ya da algı üzerinden gerçekleş- 
Özcan, E. (2017). A Žižekian reading: Discourse analysis of n11.com, Akbank \& Sinpaş GYO advertisements. International Journal of Social Sciences and Education Research, 3(3), 899-913.

tirir. Reklamlar bireylerde uyandırılan eksiklik duygusunun ancak sunulan tüketim nesnelerinin satın alınmasıyla giderilebileceği sezgisini yaratarak var olur. Bunu ise, bireye "sunulan nesneyi aldığında yaşamın daha iyi olacağını söyleyerek; ona içinde bulunduğu yaşamdan daha iyi bir yaşam önererek yapar" (age).

Kendisini öznelere birer mutluluk getirici fantezi olarak sunan reklamlar; canlı insan pratiğinin düşünsel, dilsel, psişik ve hatta maddi temsillerini üzerinde taşıyan kültürel yüzeyler olmaları nedeniyle çözümlenmeye ihtiyaç duyarlar. Bu anlamda, bu çalışmanın temel derdi; birer söylemsel form olarak ele alınan reklam içeriklerini, bu içeriklere egemen anlam örgüsü ve anlatı yapıları ekseninde incelemek yönündedir. Diğer yandan, içeriklere hakim olarak görülen semantik yapıların bilinçdışı düzeyle olan ilişkisi teorik tartışmalar eşliğinde ele alınacaktır. Bu yapılırken; bilinçdışı düzeylerin toplumsal görüngülerle olan eklemlenme noktaları da gösterilecektir. Bu çalışmada, reklam medyasının bireyleri tüketime sevk etmede başvurduğu bilinçdışına seslenme pratikleri örnek reklam filmleri etrafinda ortaya konması esas alınmaktadır. Bu kapsamda, bir sosyolog, felsefeci ve kültür eleştirmeni olan Sloven düşünür Slavoj Žižek'in popüler kültür içeriklerine uyguladığı psikanalitik çözümlemelerden yararlanılacaktır. Žižekci kavram setine dayanarak yapılacak bir okuma pratiği; "Sloven düşünürün kuramsal açılımlarının (yüksek teori) popüler kültür ürünlerinin eleştirisine uygulanabilmesinde gösterdiği uyum" (Olson ve Worsham, 2001, s.251) nedeniyle tercih edilmiştir. Yanı sıra, Žižek Lacan'a ait kimi kavramları sosyolojik olay ve olgulara doğru genişletir. İnsanın içsel güçlerine dair getirilen açıklamalar ve bu açıklamaları bir üst gösteren olarak altında toplayan kavram setlerini, toplumsal fenomenlere açıklama getirmekte kullanır (örneğin, jouissance'ı milliyetçilik/ırkçılık temelinde ele aldığı gibi). Dolayısıyla, Žižekci düşünce, reklam medyası/popüler kültür içerikleri ve kültürel alımlama pratiği arasındaki ilişkiyi psikanalizin ortaya koyduğu tartışmalar ve kavram setleri ekseninde anlamaya, bunu da sosyolojik olanla birleştirmeye çalışan bu çalışmanın amacına uygun bir teorik ve yöntemsel perspektif sunmaktadır.

Bu çalışmada,- "bilinç dışının bilimi”ni kuran Fransız psikanalist Jacques Lacan'ın (1978) ortaya koyduğu düşünsel mirastan beslenen; "Lacan'ın çekiciyle put kıran" (Rigel, 2014, s.295)- Žižekci terminoloji içerisinde öne çıkan "artık keyif”, "jouissance", "obje petit a", "Simgesel”, "yamuk bakmak" ve "mekanik” 1srar gibi kavramları ele alınacaktır. Bu kavramlar, bir süre öncesinde kitlesel dolaşıma girmiş ve popüler söylem içerisinde kendisine sıkça yer bulmuş n11.com, Akbank ve Sinpaş GYO gibi reklam filmlerinin analizinde kullanılacaktır. Üç bölümden oluşan çalışmanın ilk bölümünde n11.com reklam filminin alımlayıcısına/tüketicisine vaat ettiği "jouissance" kırıntısı, aynı içeriğin göze görünmeyen kör noktalarına temas edilerek çözümlenecektir. Takip eden bölümde, "Simgesel”in vücut bulduğu bir form olarak Akbank reklam filmi tartışılacak, reklamın mesajına "yamuk bakılarak" simgeselleştirilenin semptomları açığa çıkaralacaktır. Çalışmanın son bölümünde, patriarkal toplumsal yapının kurucu öznesi Pater'in mekanik geri dönüşünü örnekleyen bir reklam anlatısı olarak Sinpaş GYO reklam filmi tartışılacaktır.

\section{2. "Artık-Keyif" ve "Objet Petit A": Budur! "Bu" Nedir?, n11.com reklam filmi}

Lacan, "Marx kapitalizmi günden güne büyüten "artık-değer" kavramına kafa yormamış olsaydı "artık-keyif" üzerine yoğunlaşırdı" (Lacan, 1969-1970, s.141) demiştir. İşte tam da bu nedenle "artık keyif” kavramını öncelikli olarak Marx'ın "artık-değer" sorunsalıyla birlikte düşünmemiz yerinde olacaktır. Marx'ın Adam Smith ve David Ricardo gibi klasik ekonomi politikçilere kıyasla farklı bir yönelimle ele aldığı "artık-değer" teorisi; sermayenin işçinin üretken 
Özcan, E. (2017). Bir Žižekci okuma: n11.com, Akbank \& Sinpaş GYO reklam filmlerinin söylemsel analizi. International Journal of Social Sciences and Education Research, 3(3), 899-913.

emek faaliyetiyle üreterek geride bıraktığ ${ }_{1}$ artık-değere, yani işçinin saatte ya da herhangi bir emek-zaman biriminde ürettiği parasal değere el koyduğu argümanı üzerine temellenir. Marx’a göre işçinin emeği karşıllğında aldığ 1 ücret, ürettiği toplam değerin ancak bir kısmına eşdeğerdir (1998). Lacancı manada bakıldığında ise, sermaye, işçiye üretken emek faaliyeti karşılığında "eksikliği" (1978) sunmaktadır. Burada paradoksal olan; işçinin yenilenen bir üretici çevrimde yer almak dışında pek de bir şansının olmamasıdır. Yine paradoksaldir ki, işçinin emek gücünün varlığı, karşılığ değerin yeniden üretilmesine bağlıdır. Lacan'ın "artık keyif” kavramına geri döndüğümüzde; Žižek, şeylere karşı duyulan arzunun yeniden üretiminde arzuların dairesel yoluna gerisin geri dönerek yinelendiğini ileri sürer. Sloven düşünüre göre bu durumu kapalı bir çevrim olarak adlandırmak da mümkündür. Bu türden bir çevrimi var eden asıl keyif kaynağı; öznenin söz konusu çevrimi yinelemeye dönük eyleyişidir (2013, s.18). Özne gündelik yaşamı içerisinde kaç1nılmaz olarak yinelediği bu çevrim karşılığında; "simgesel düzene eklemlenmek pahasına sarf ettiği jouissance ${ }^{2}$ kırıntısını” (Žižek, 1997, s.48) elde eder. Bir başka deyişle, artık-keyfi var eden ve onu yeniden üreten şey; öznenin israrla peşinde koştuğu tatminin kendisi değil, tatmin edilmeye dönük arzularının yeniden üretimidir. Özne gidermek için çabaladığı tatminin karşılığında, işçinin el konulan emek faaliyeti karşılı̆̆ında kendisine sunulan eksikliğe benzer şekilde, geçici bir tatminden başka bir şey edinemez.

Medya profesyonellerinin tüketicilerin psikodinamik dünyalarını hedeflediği; artık-keyfi harekete geçirmeye dönük alt metinleri reklam kampanyalarında kullandıkları bilinir. Ticari değer yaratımı ya da kar rasyonalitesi içerisinden bakıldı̆̆ında; reklam yazarlarının tasarladıkları mesajların artık-değerin yeniden üretimine dönük itkilerle töz bulduğu/şekil aldığı rahatlıkla söylenebilir. Bu tür bir kipliğin çıktısı olarak okunabilecek reklam metinlerinden birisi de n11.com adlı e-alışveriş sitesinin tanıtımının yapıldığı reklam kampanyasıdır. n11.com temelde "elektronikten tekstile, mutfak gereçlerinden Türkiye'nin nadide el sanatlarına kadar farklı ihtiyaç ve zevklere hitap eden milyonlarca ürün, alışveriş yaptıkça kazandıran yapısı ile üyelerine yeni bir alışveriş deneyimi sunan" (n11.com, 2012) bir çevrim içi alışveriş sitesi olarak tanımlanabilir. Haziran 2012'de kurulan sitenin reklam kampanyası muhtelif medya kanalları aracıllğıyla duyurmuş, site hizmet tanıtımlarında Sergen Yalçın gibi tanınmış yüzlere yer vermiştir. n11.com reklam filmimin hikayesi ayakkabı topuğunu kıran bir kadının yaşadıklarına odaklanır. Batılı görünüm ve modern giyim kuşak rejimini yansıtan reklam yüzü, kafede yürürken ayakkabasının topuğunu kırar ve soluğu n11.com'u imgeleyen uğur böceğinin yol göstermesiyle kendisini sürüklediği çevrim içi ortamda bulur. Ortamın kendisi farklı tercih, beğeni ve amaçlara uygun çeşitli türde tüketim nesnesinin akıp gittiği bir tür meta payanırıdır. Reklam yüzü çevrim dışından geçerek girdiği panayırı dolaşır ve bu sırada topuğu kırılan ayakkabasının benzerini bulur. Reklam yüzünün içerisinden kat ederek geçtiği dolayımlayıcı yüzeyin, yani kişisel laptopun

\footnotetext{
${ }^{1}$ Lacan eksik ya da eksikliği (lack) çocuğun dil öncesinde anne bedeninden ilksel ayrılması sonucunda bir uzvunun hadım edilmesi şeklinde açıklar. Lacan'a göre bu durum çocuğun dil evrenine adım atmadan önceki döneme geri dönüş ihtiyacı şeklinde görülür. Özne dilin alanına girip bu eksiği simgesel olarak ifade etmeye başladığında eksik ya da eksiklik, öznenin karşısına tatmin edilmesi mümkün olmayan bir arzu olarak çıkar (1978, s.282).

2 Fransızca bir sözcük olan jouissance İngilizce'ye bliss ya da enjoyment olarak çevrilmiştir; Türkçe'de ise keyif terimiyle karşılanmaktadır. Žižek'in belirttiği gibi Lacan bu kavramı Freud'un "haz ilkesi” olarak adlandırdığı şeyin ötesine yerleştirmektedir. Buna göre, Freud'da haz (lust) bedensel/ruhsal bir gerilimin boşalmasından ibarettir. Dolayısıyla, haz bir tatmin ve rahatlama duygusuyla birlikte anılır. Oysa jouissance basit bir tatminin ötesinde, bir "dürtü tatmini”dir ve bu nedenle imkansızdır. İlksel eksikliğin (anneden koparılmış olmanın) giderilmesi arzusunun gerçek bir tatmini yoktur, ancak psikotik bir durumda mümkündür bu tatmin. Jouissance ise bu eksiğin giderilmesi fantazisini yaratarak kendisini “Gerçek”te temellendirir (2013, s.230).
} 
Özcan, E. (2017). A Žižekian reading: Discourse analysis of n11.com, Akbank \& Sinpaş GYO advertisements. International Journal of Social Sciences and Education Research, 3(3), 899-913.

sahibi ise aynı kafede oturan bir erkektir. Kadın oyuncu bir süreliğine dahil olduğu panayırdan gördüğü ayakkabıyla yetinmez; erkek oyuncunun laptopundan ortaya firlayan kulaklığı ona alır (Youtube, 2013).

Resim 1. n11.com reklam görseli

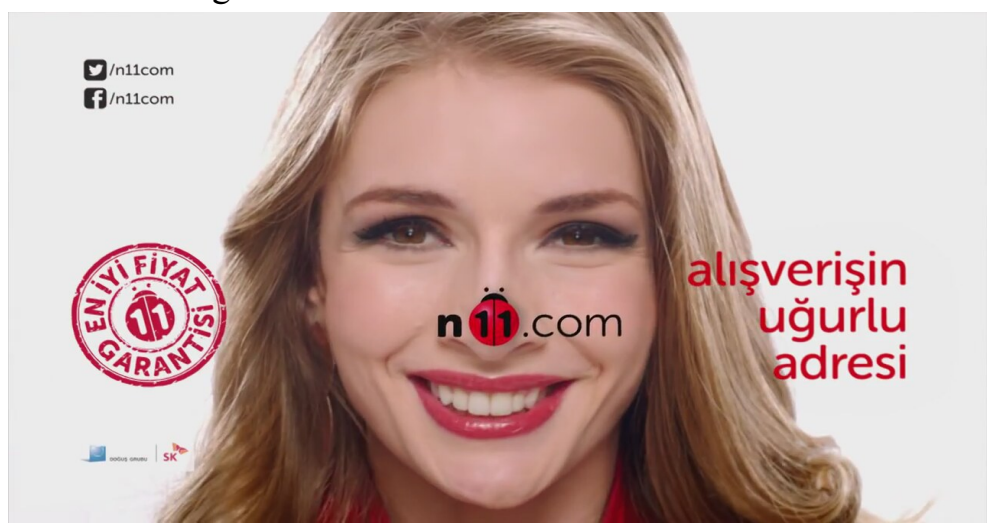

Kaynak: http://www.alisverisrehberi.com/reklamlar/n11_com_acilis_kampanyasi.2525.html

n11.com reklam müziğinde (kadın ve erkek) dış sesin tekrarladığı "n11.com, Budur!" sloganı; kadın ve erkek izler kitlenin dikkat ve ilgisine eğilir. n11.com reklamı, ilk bakışta, çevrim içi ortamda sergilenen tüketim edimlerinin aslında gündelik yaşamda sergilenen tüketim edimlerinden pek de farksız olmadığ rişlerin kolay ve "sürprizlerle dolu" (indirimler ve hediye kuponları gibi) olduğunu imleyen bir anlam örgüsü hâkimdir. Reklam sloganının ana gövdesini oluşturan ve sloganı algıya mıhlayanbunu sloganın orgazm noktası olarak da yorumlayabiliriz- "Budur!" önermesi; belirsiz/bilin(e)meyen bir meta formuna işaret eder. Meta formunu gösteren "Budur!" sözcügü, daha çok gündelik dilin kendini farklı çağrışımlara kapatan göstergelerinden biri olarak karşımıza çıkar. Ne var ki gündelikli, aşina olunan reklam dilince içerilerek modüle edilir. Gündelik dilde sıklıkla kullanılan ve çağrıştırdığı yan anlamları dolayısıyla tamlığı/bütünlüğü/kusursuzluğu ifade eden "Budur!" ibaresi,- her ne kadar göze gelmese de- toplumsal emek faaliyetinden geriye kalan ve sermayenin iştahla el koyduğu artığı temsil eder. Emeğin ürününü soyutlayarak kendi bünyesinde soğuran "Budur!" göndereni, tüketiciye boşlukları özenle örülü bir tamlık/bütünlük hali vaat eder. Fakat "büyük a ${ }^{1}$ asla arzu nesnesiyle örtüşmeyez ve duyulan arzuyu tam olarak yatıştıramaz” (Boyle, 2008, s.8-9). Sermaye öznenin jouissance'1 elde etmeye yönelik çabalarının karşısına tunçtan yasalarını çıkarır ve reklam metinleri yoluyla üretilen iletiler, öznelere "tüketimde ve tüketime dönük tercihlerinde" aktif olmayı telkin eder. Sermaye, öznenin yerine getirdiği tüketici failliği karşılığında, ona asla tam olarak tatmin edilemeyecek arzularını dindirecek kısmi/palyatif tatminler sunar. Böylece, öznenin tatmin edilmeyi bekleyen arzuları da yeniden üretilmiş olacaktır.

Buradan hareketle, öznenin nasıl olup da inatla/1srarla- n11.com örneğinde adeta bir boş gösterene dönüşen "Budur!'” önermesi ile gösterilmeye çalışıldığı gibi- tatmin edilemeyecek arzularının peşinde koştuğu sorusunu sormak yerinde olacaktır. Bu sorunun cevabı Lacan'cı neolo-

\footnotetext{
${ }^{1}$ Büyük a Žižek'in açıkladığı gibi simgesel düzenin ta kendisidir. Hitap edenin içinde varolduğu simgesel sistemin belirleyicilerinin toplamıdır. Burada özne, kelimenin psişik ve gramatik anlamında bir "özne" olabilmesi için, simgesel düzende büyük Öteki ile karşılaşmak zorundadır. Büyük Öteki eksik'i gizli tutularak tüm arzunun mekanı olarak kurulur; bu mekanı Babanın-Adı, devlet, Tanrı, yasa kısacası özne için simgesel düzenin bütünlüğünü temsil eden herhangi bir şey doldurabilir (2013, s.231).
} 
Özcan, E. (2017). Bir Žižekci okuma: n11.com, Akbank \& Sinpaş GYO reklam fillmlerinin söylemsel analizi. International Journal of Social Sciences and Education Research, 3(3), 899-913.

jizmin başucu kavramlarından objet petit a kavramıla verilebilir. Žižek'e göre özne, kültür ve dilin alanına geçmezden evvel annesiyle birlikte yakaladığı tamlık/bütünlük halini kaybeder. Özne bunun sonucunda tam olarak bilmediği bir "şey"i yitirir; objet petit a ya da "arzu nesnesi" olarak da bilinen bu şeye ulaşmak ister ve onu bıkmadan arar. Bulamayacağını bildiği halde onu aramaktan vazgeç(e)mez. Gelgelelim ki, onu asla bulmak niyetinde de değildir. Duyumsadığı eksiğin yerine hep büyük a'ları koyar ve eksiği böylece doldurmak ister. Yine de ne yaparsa yapsin eksiği doldurmayı beceremez (2013, s.230-231). n.11.com reklam filmi örneğinde de görüldüğü üzere, öznenin tam olarak ne olduğunu anlayamadığı "Gerçek’in "fazlası" (s.231) özneye kısmi tatmin parçacıkları olarak sunulur. Tatminin kendisi tüketime indirgenirken, doyum sağlama iddiasında bulunan partiküller (buna reklam metnine gömülü ikna ve mobilize edici alt metinler de diyebiliriz) öznenin doldurmaya uğraş verdiği eksiği ortadan kaldırmak bir yana, onu yeniden ve yeniden üretmeye hizmet etmekten başka bir şey yapmaz.

\section{3. "Simgesel"e "yamuk bakmak": Akbanklı hep mi farklı?}

Öznenin tam olarak ne olduğunu anlayamadığı "Gerçek” nedir? Lacan bu soru üzerine henüz 1953 'te düşünmüş ve "gerçeğin sadece simgeleştirilemeyen, dolayısıyla da simgeselin dışında bırakılan bir şey olduğu" (Evans, 1996, s.173) yanıtını vermiştir. "Gerçek" kültürel belirlenimlerin dolayımlayamadığı, simgeselleştiremediği şeydir ve bu açıdan "Simgesel”le ilişkilidir. "Gerçek", "Simgesel”"in dışında konumlandırılır; kapsanmamış olandır. Bu da, Rigel'in ifade ettiği gibi, "Gerçek"in her şeyden önce, dil öncesi, yani insan öncesi bir konuma yerleşmesi demektir. Ontogenetik açıdan, henüz konuşamayan ve imgeler oluşturamayan bebeğin tüm deneyimi "Gerçek"in alanına girdiği gibi, filogenetik açıdan da, insan öncesi olan her şey, dolayısıyla "Doğa" dediğimiz şey de "Gerçek”tir" (2005, s.312). Şu halde, "Simgesel” gerçekliği kendi içinde dolayımlayarak ona ulaşmamızı sağlayan bir tür kodlayıcı, sembolik/yapısal şematiktir. Žižek'in gösterdiği gibi gerçek ancak simgesel aracılığıyla işler ve ona simgesel aracılığıyla ulaş1labilir (2002, s.41). "Simgesel” "Gerçek”in kurulduğu, öznenin kültürel ağlar aracıllğıyla çağrıldığı (interpellate), yani "ben" diyerek özneleştiği dilsel, gramatik ve kültürel yapıdır" (Žižek, 2013, s.232). "Simgesel”in kendi içinde teyelleyemediği, bir türlü taşıyamadığı sert çekirdek, yani "Gerçek", öznenin "Simgesel”"in alanına girişiyle birlikte içinde bulunulan bir durum olmaktan çıkar ve bir daha ulaşılamamak üzere geride kalır. "Çünkü onu, bizi gerçeklikten ayıran dil evreninin içerisinde ifade etmemiz mümkün değildir” (Dino, 2014).

"Simgesel" ya da bir başka deyişle, ideolojik-kültürel evrensellik tutarlılık, söylemsel kapalılık ve bir tür normatif üstünlük ve doğruluk iddiası gösterse de, bu simgeselleştirimin aksadığı, kopukluk gösterdiği ve bu noktada tikel sapmaların olmadığı anlamı taşımaz. Simgeselleştirilmiş olana farklı açılardan bakıldığında, bünyesinde içkin olarak var olan bozucu unsurların ortaya çıkabildiği görülür. Bu çözücü, tutarlılık bozucu unsurların her biri esasında birer "semptom"dur. "Semptom", Žižek'in deyişiyle, "verili bir ideolojik evrenden farklı, ondan ayrıksı bir bozulma noktası olmakla birlikte, aynı ideolojik evrenin kendi kapanımını gerçekleştirerek dile gelmesine de olanak sunar" (1989, s.21). Semptom, "bir istisna olarak, yani evreni evrensel ilkenin askıya alınma noktası olarak kalmak zorunda olan bir unsurdur” (Žižek, 2011, s.160). Bu unsur ya da unsurların çözündürülerek görünmeyenin yüzeye çıkarılması ancak belli bir açıdan bakılarak olur. Žižek'in anamorfotik cisimler dediği sembolik/maddi şeyler belirli bir (ve sıradan olmayan, aykırı) bakış açısından, "yamuk bakarak" algılanabilir ve ancak bu sayede Simgesel düzende bir yere oturtulabilir. Bu, nesnelerin görme duyusuyla dolaysız olarak algılanamadığı, belli bir biçime sahip değilmiş gibi görünen nesnelerin özel bir bakış açısıyla algılanabilir 
Özcan, E. (2017). A Žižekian reading: Discourse analysis of n11.com, Akbank \& Sinpaş GYO advertisements. International Journal of Social Sciences and Education Research, 3(3), 899-913.

olduğunu gösterir (2013, s.227). Dolayısıyla, “Simgesel"in kodladığı/anlamlandırdığ1, dilin ve göstergelerin töz kattığı nesnelerin ya da daha geniş anlamda söylemlerin, dosdoğru bakıldığında göstermediği alt metinler bulunur. Bu mesajlar ancak belli, maksatlı bir açıdan, yamuk bakılarak görülür ve anlaşılabilinir.

"Simgesel”, kültürel anlam yapılarına ya da bir başka deyişle, toplumsal söyleme gömülüdür; bu yapılar içerisinde/dolayımıyla ifade bulur. "Simgesel"in içerisine iliştirildiği görünümlerden biri de popüler söylemin bir parçası olan reklam metinleridir. Reklamlar, gündelikli olanı ticari, pazarlamaya dönük mesajlar altında ideolojik olarak yansız, nötr gibi yansıtsa da, "her zaman basitçe gerçekliğin parçası olmaz; başka bir gerçekliği yansıtır ve kırılmaya uğratır (...). [İşin asl1;] nerede bir gösterge mevcutsa, orada ideoloji de mevcuttur" (Voloşinov'dan aktaran Hall, 2003, s.218). Bir tür eleştirel çözümleme pratiği olarak da görebileciğimiz "yamuk bakma" eylemi bize bu yansıtma ve kırılmalar anlarını işaretlemede e yardımcı olurken; ideolojik olarak bükülmüş mesajları karşıt söylemlerle yerli yerine oturtmamızı da sağlar. Yukarıda da bahsedildiği gibi gerçekliğin kırıldığı ve toplumsal alana taşındığı aygıt ve alanlardan biri de medya ve yaydığı mesajlardır. Toplumsal gerçeklik, diğer pek çok kitle iletişim formu yanı sıra (haberler, diziler, belgeseller ve sinema benzeri içerikler gibi) bir kültürel yüzey olma niteliği ve taşıyıcı/dolayımlayıcı işlevi bulunan reklamlar yoluyla kurulur, yeniden üretilir ve kitlesel dolaşıma sokulur. Akbank'ın “Akbanklı Hep Farklı” sloganıyla duyurduğu reklam filmi de bu mesajlardan biridir. 2013 tarihinde servis edilen Akbank reklamı temelde "ayrıcalıklı hizmet" sloganına yaslanır. Film Ali ve Nuri adlı ikiz erkek kardeşlerin gündelik yaşam deneyimleri ve bu deneyimlerin dönüp dolaşıp bağlandıkları bankacılık tercihleri üzerine kurulur. Ali ve Nuri ikiz kardeştirler fakat ikiz olsalar da zıttırlar; bu yüzden adları "zıt ikizler"dir. Kardeşlerin yaşadıkları gündelik olayları konu alan Akbank reklam kampanyası; ikiz kardeşlerin karakter özellikleri, beğenileri, ilgileri, dış görünüşleri ve elbette bankacılık tercihleri arasında mizahi denebilecek bir zıtlık ve ironi ekseninde işler. Kardeşlerden Ali akılcılığıyla "rasyonel bireyi”" temsil ederken, Nuri üzerine düşünülmemiş, özensiz tavır ve hareketleriyle "irrasyonel" olanı kimliklendirir. Ali Akbanklıdır ve aldığı bankacılık hizmetleriyle hep bir adım önde, hep avantajlı konumdadır. Ali almış olduğu kararlar ve akılcı tercihleriyle yardıma koşarken; Nuri ise ölçüp tartmadığı karar ve davranışlarıyla hep zor durumda kalır ve yardım bekleyen taraftır (Youtube, 2013).

Resim 2. Akbank reklam görseli

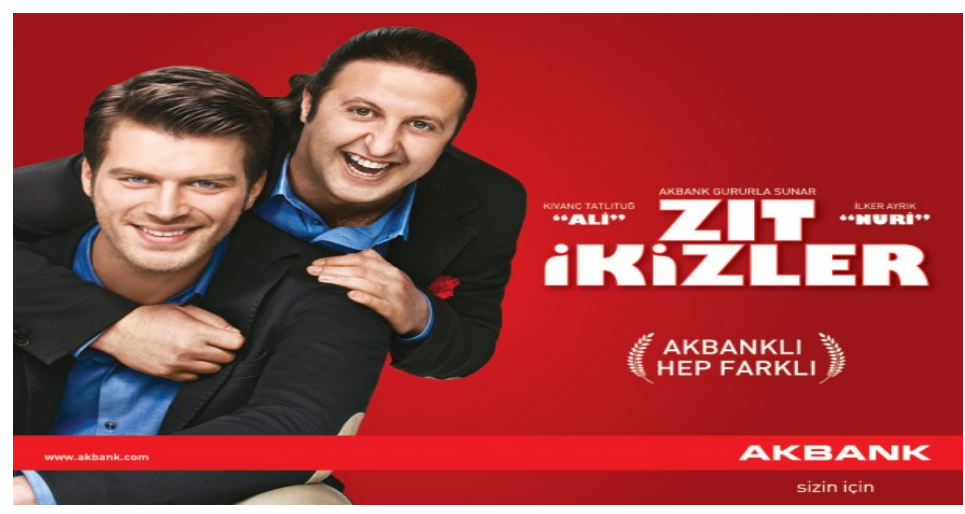

Kaynak: $\quad$ http://www.campaigntr.com/2013/03/14/37171/akbank-yeni-kampanyasiniduyurdu-zit-ikizler/ 
Özcan, E. (2017). Bir Žižekci okuma: n11.com, Akbank \& Sinpaş GYO reklam fillmlerinin söylemsel analizi. International Journal of Social Sciences and Education Research, 3(3), 899-913.

Akbank reklam filmi, Akbank’ın müşterilerine sağladığı hizmet standartlarıyla benzerlerinin ötesine geçtiği mesajını verir. Buna göre, diğer bankaların bankacılık hizmetleri sıradan ya da standartdır, ne var ki Akbank'ın vaat ettiği "benzersiz hizmetler" bu bankayı rakip bankalara kıyasla ayrıksı, ayrıcalıklı bir yerde konumlandırır. Bu noktada şunu not etmeden geçmemek gerekirse; Akbank'ın ayrıksılığı parçalar arası ilişkiyle, yani rekabet halinde bulunduğu diğer bankalarla arasında olan karşılıklı ilişkinin içsel mantığı ve görünümlerinden ibarettir.

Akbank'in farklllık mitosuna başvurarak sunduğu hizmetler, tüm rasyonelliği ve pratik konvansiyonlarıyla (iş ahlakını tanımlayan genel kurallar, ilkeler ve uygulama rasyonalitesi gibi) biçimsel olmanın ötesine geçemez. Bu nedenle, farklı olma vurgusuyla işaret edilen özde değil ama daha çok yüzeyde temsil bulan biçimdir. Bu rezervi bir kenara koyarak devam edersek; vermiş olduğu ya da vaat ettiği bankacılık hizmetleriyle farklı olanın, olduğu iddia edilen sadece Akbank'ın kendisi değildir. Kurumsal bir yapı olarak Akbank'ın sunmuş olduğu hizmetlerden faydalanan tüm mudiler de diğer bankaların müşterilerine kıyasla ayrıksı, avantajlı bir konuma sahiptirler. Ayrıksılık/ayrıcalık alanında konumlanmamış olanlar, yani Akbanklı olmayanlar ise ancak Akbanklı olmaları durumunda sunulan farklılar ligine dâhil olabilir ve farklılık ufkunu deneyimleyebilir. Bu noktada, Akbank izleyicilerin/tüketicilerin biliçdışına seslenerek, onlara bir fantazi olarak farklılıklar ve de farklı olanlar ligini vaat eder. Bu lig, temelde, Freud'un ruhsal etkinliğin hazsızlık üretebilecek her tür olaydan geri çekilmesi olarak tanımladığ 1 "haz ilkesi” (2011, s.13) üzerine kuruludur. Buraya üye olabilmişşsanslı bireyler, Akbank'1 tercih etmelerinden dolayı farklı, ayrıksı ve benzersiz olma konumuna sahip olarak geçici bir hazza varabilecektir.

Akbank reklam filmi, izleyiciye farklılığın, ayrıksılığın mümkün olduğu mesajını verir; bunun da, bireylerin kişisel tercihleri, seçimleri yoluyla gerçekleşmekte olduğuna işaret eder. Akbank reklam filmi, Akbanklı olmaya karar veren izleyiciyi farklı olmayan/benzer ötekilerden ayrışabileceği sanısına sürükler. Gelgelelim, "Simgesel” in açmış olduğu cul de saclar (çıkmaz sokakları) unutulur ve izleyiciye- örtük olarak- unutturulmaya çalışılır. Başka bir açıdan, ya da maksatlı bir okumayla bakıldığında (muhalif bir okumayla); "Simgesel”in seçme özgürlüğü değil ama daha çok seçememe özgürlüğ̈̈ ya da seçme zorunluluğu sunduğu pekala söylenebilir. $\mathrm{Bu}$, esasında, "Simgesel"in bozucu tikel unsurlarının açığa çıkarılabileceği ana işaret eder. Akbank reklamının dosdoğru bakışla göstermedikleri ancak ona belli bir açıdan bakıldığında görünür olabilir. $\mathrm{Bu}$, bir anlamda, mesajın yüzeyde göstermediği imin seçilerek cımbızla bilince taşınmasıdır. Akbank reklamıyla ifade edilen "seçme özgürlüğü", bir söylem olarak kapalılık (dolayısıyla normatif üstünlük iddiası) ve geçerlilik ısrarı taşır. Bu ise, farklı anlamlar şebekesi içerisinde yeğlenen gösterenlerin kendisini doğalmış gibi yansıtmasıyla, göstermesiyle mümkün olur (herkes gibi şu ya da bu nedenle, şu ya da bu şeyi/insanı seçmez miyiz?, seçimlerimizi bizzat kendimiz, istediğimiz için yapmaz mıyız?). "Seçme özgürlüğü" söylemi gerçekliği tanımlar ve onu "Simgesel"in içinde konumlandırır. Her bir simgeselleştirme pratiği, toplumsal anlamları diğer anlamlarla olan ilişkisinde sabitlemeyi getirir ki bu da algı düzeyinde benzer bir sabitliliğe yol açabilir. Algılanamayan mesaj ve altında yatan imleri; algı duvarına her çarpılışında daha da yer eder ve orada tutunmaya çalışır.

"Simgesel”in semptomları, yani bu bağlamda "seçme özgürlüğü" nosyonu/söylemi sosyalizasyon ve bireysel arzu rabıtası üzerinden açımlanabilir. İlkin, "Simgesel”, özneyi, "olumsuz dolaylı eylem"de (action indirecte négative) bulunma, yani Baker'in bahsettiği gibi öznel güçlerini (bilişsel, duygulanımsal ve maddi) harekete geçirererek, materyal ve/ya simgesel olana ya- 
Özcan, E. (2017). A Žižekian reading: Discourse analysis of n11.com, Akbank \& Sinpaş GYO advertisements. International Journal of Social Sciences and Education Research, 3(3), 899-913.

tırmama özgürlügünden (2012, s.24) alıkoyar. "Simgesel"in ilan ettiği, dolaşıma soktuğu "seçme özgürlüğü" kendi içinde antinomiktir; işaret ettiği ya da bir başka deyişle, orta yerinde kurulduğu günümüz tüketim toplumlarında, özneler, tüketim nesnelerini tüketmeksizin, bu nesnelere sahip olmaksızın var olmaz. Bu manada; tüketim, toplumsal söylem içinde, bireyin özgür seçim ve beğenilerine dayandırılır; tüketim edimleri özgür seçim ve kişisel beğenilerle eşleştirilir. Ne var ki bireyin seçimi toplumsal uzama kültürel anlamlar yoluyla-yani negatif bir fiziki güç/baskı kullanmaksızın-, yani yumuşak güç (ideolojik ikna ve telkin, sosyalizasyon süreçleri) yoluyla dayatılır. Marcuse'ün dediği gibi günümüz nomosu bizlere kendimizi tüketim ürünlerini edinerek tanımlayabileceğimizi öğretir. Bizler ürün ya da hizmetleri "modası geçtikleri" (out of fashion) ya da çabucak yıpranarak eskidikleri için, yerlerini yeni ürünler alarak doldurmayı öğreniriz. Bu durum, boşluğa yer bırakmasızın gerçekleşir ve kitle medyası ve reklam içerikleri ideoloji yüklü mesajlarla boşlukları doldurur. Artık, tüketim kültürünün dışında ayakta kalarak yola devam etmek mümkün değildir; yalnızca yapmış olduğumuz tüketim tercihleri yoluyla edindiğimiz kimlikler vardır ve bunlar olmaksızın var olabileceğimiz düşünülemez (1991, s.321). "Seçim özgürlüğü”nün gösterdiği "bireysel seçim” ve “özgürlük”tür. Şu var ki, aslında özneler şu ya da bu şekilde seçimde bulunmak, beklemeksizin eyleyişe geçmek zorundadır. Burada esas olan; "özgür seçim” göstereni altında kodlanmış bir edimi yeniden üretmek dışında pek de bir şey yap(a)mıyor oluşumuzdur ki tam da bu noktada karşımıza bireysel arzular çıkar. Žižek'in belirttiği gibi, öznenin kısıtlanmaktan çok, rahatlıkla cazibenin akımına kapıldığı, kendisini çekici olanın kollarına bıraktığı günümüz post-liberal toplumlarında id (arzu) ve süperego (iktidar) uzlaşmış, süper-ego- özneyi kısıtlamak ve engellemek bir yana- ona "keyfine bak!" diyerek "baskıcı hazzın" (repressive desublimation) ağırlığı altına girmiştir (1994, s.16). Baskıcı hazzın ağırlığı tam anlamıyla rahatsız edicidir. Herkes tüketecekleri arasından bir seçim yapıyorken bizler de seçim yapamıyorsak ya da herkes tüketirken tüketemiyorsak bir şekilde tedirgin oluruz. Tedirginlik Cremin'in dediği gibi doğrudan egoyu kemirir; herkes tüketiyorken tüketmiyorsak ya da herkes eğlenirken eğlenmiyorsak acaba bizde mi bir problem var diye düşünmeden edemeyiz (2011, s.52). Bu noktada, arzularımızı bir an için açığa taşır; bize hazzı vaat eden seçimleri yaparak hazzın anlık baskısına boyun eğeriz. Dolayısıyla, dil/dilin imi, toplumsal süreçler veya psişik belirlenimler hesaba katıldığında; "seçim, seçme özgürlüğ̈̈" denen şeyin var olmadığı ve esasında bir tür fantazi olduğu pekala söylenebilir.

\section{Mekanik Israr: Pater'in geri dönüşü, Sinpaş GYO reklamı}

Žižek yaşayan ölülerin dönüşünün fiziksel yok oluştan sonra bile geçerli kalacak bir art1$\breve{\mathrm{g}}$ /simgesel borcu temsil ettiğini ileri sürer. Buna göre, ölüler, yaşamları boyunca kendilerine borçlanılan simgesel borçları tahsil etmek üzere hortlayıp geri dönecektir (2013, s.40). Ölüleri dünyaya geri dönmeye sevk eden, yani onları borcu kapatmaya iten şey ise arzudan başka bir şey değildir. Arzu ısrarcıdır ve Žižek'in ifade ettiği gibi talep ettiği şeyden vazgeçmez. Bu, karmaşık diyalektiğe yakalanmayan "mekanik" bir ısrardır. Talep öncelikli olarak doğar; bunda sonsuz biçimde 1 srar edilir (s.37). Ancak, talep diyalektik dolayıma yakalanmaktan da kurtulamaz. Çünkü "bir şey talep ederiz, ama aslında bu talep yoluyla başka bir şeyi- hatta bazen talebin düz anlamının reddini- hedefleriz" (age). İki ölüm arasında hortlayan hayaletler, giderilmesi zorunlu ısrarları için hayata döner ve onun peşinden koşar. Burada Žižek'in gösterdiği gibi iki ölümden kasıt; biyolojik anlamda zorunlu olan ölüm ve öznenin huzur içinde, yaşadıklarının hesabını görerek, belleğini zapt edecek herhangi borcu olmadan ölümüdür. Ölülerin geri dönüşü usulünce yapılmamış bir cenaze töreni gibidir. Biz onları usulünce gömene, ölümleriyle bilince 
Özcan, E. (2017). Bir Žižekci okuma: n11.com, Akbank \& Sinpaş GYO reklam fillmlerinin söylemsel analizi. International Journal of Social Sciences and Education Research, 3(3), 899-913.

çıkan travmaları belleğimizde taşıyana değin bizleri takip etmeyi sürdürecektirler (2004, s.40). Aksi halde, ölüler, tıpkı var oluşunun izleri eski çağlara değin sürülen Pater gibi şimdinin anlatı biçimlerinde dahi karşımıza dikilirler. Pater $^{l}$ yani "Baba" figürü hâkim/devindirici söz ve eylem setiyle modern toplumların izini sürer. Örneğin, modern bir olgu olarak kapitalist sermaye tüm pragmatizmiyle Pater'in içsel mantığına, onun ortaya koyduğu norm ve değerlere eklemlenmekten geri durmaz. Finanse ettiği reklam filmleri benzeri metinler, hâkim erkek egemen anlatı ve imgeleri işleyerek, kamusal dolaşıma taşır. Açık ya da örtük, medya profesyonelleri aracıl1ğıyla reklam içeriklerine iliştirilen bu mesajlar; erkek egemen toplumsal gerçekliğin üzerinde yükselerek onun kamusal anlatıcılı̆̆ına soyunur. Bu aynı zamanda, Pater'in mekanik bir ısrarla hortlaması demektir.

Sinpaş 40.yıl AltınOran reklam filmi toplumsal gerçekliğin kamusal anlatacılığına soyunan ve onu yeniden üreten çeşitli medya içeriğinden biridir. Toplu konut üreticisi Sinpaş GYO'nun televizyon ve radyo medyası benzeri farklı kanallar üzerinde yer bulan reklam filmi, temel olarak, evli ve çocuklu çiftlere seslenerek onları uygun ödeme koşullarıyla "hayallerinde yatan" eve sahip olmaya çağırır. Reklama hâkim ileti "doğallı̆̆ı" ve "masumiyeti" simgeleyen bebek figürlerce dillendirilir. Bebek oyuncular odalarında oyun oynarken dış sesin betimlediği anlatıyı beden dışavurumlarıyla somutlaştırırlar. Bebek yüzlerin kullanımıyla izleyicinin algı duvarına çarpılan masumiyetin berisinde yine aynı izleyici üzerinde uygulanan "simgesel şiddet" (Bourdieu ve Wacquant, 2003) olgusu yatar. Bedene kişinin kendi rızası/onayı olmaksızın kazınan açık şiddetten farklı olarak, simgesel şiddet, Bourdieu ve Wacquant'ın belirttikleri gibi toplumsal eyleyiciler üzerinde kendi suç ortaklıkları olmaksızın uygulanamaz. Bu durum ise, ancak toplumsal grupların habituslarıyla açıklanabilir (2003, s.166).

Resim 3. Sinpaş 40.Yı1 Altın Oran reklam görseli

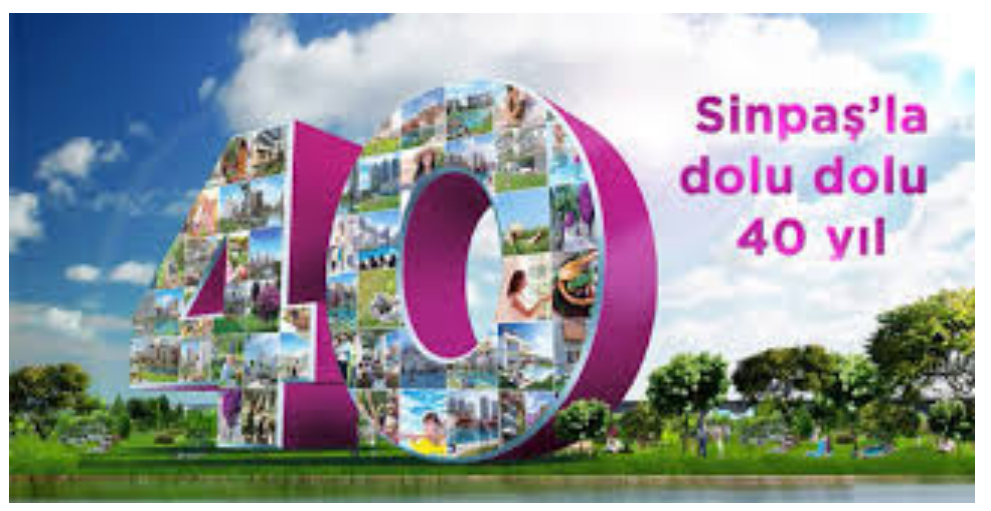

Kaynak: http://sinpasbursamodern.com/BasinReklamFilmleri.aspx

Sinpaş GYO reklamı, bireylerin/grupların toplumsal konumları gereği (bu örnek bağlamında evli ve çocuklu orta-üst sınıf aileler) taşıyıcısı oldukları toplumsal sınıf üyelerini; benzer pratik, üslup birliğine yani belirli bir eğilimsel tipolojiye sahip bireylerin habituslarını hedef alır. Bu, orta-üst sınıf bireylerin bağlı oldukları toplumsal konuma içkin yaşam stilleri, ilgi alanları, beklentileri, tercihleri ve de kültürel zevkleriyle suç ortaklığ içerisinde gerçekleşir. Öte yandan, söz konusu suç ortaklığı ve/ya gönüllü işbirliği salt kendinde bir şey olmakla kalmayıp, kişilerde eylemselliğe, doğrudan eylemi doğurmaya yol açar. Toplumsal eyleyiciler ya da Sinpaş GYO reklamı bağlamında düşünüldüğünde ebeveynler; gelecek yaşantılarına yönelik somut kararlar

${ }^{1} \mathrm{http}: / /$ www.etymonline.com/index.php?allowed_in_frame $=0 \&$ search $=$ pater 
Özcan, E. (2017). A Žižekian reading: Discourse analysis of n11.com, Akbank \& Sinpaş GYO advertisements. International Journal of Social Sciences and Education Research, 3(3), 899-913.

alarak, bu kararlar doğrultusunda harekete geçmeye, toplumsal konumlarını/yaşamlarını devindirmeye (elbette tüketim yoluyla) çağırılırlar.

Sinpaş'ın reklam yüzleri erkek ve kadın cinsini temsil eder (bunu bebeklerin Mavi ve Pembe renkli pijamalarından anlıyoruz). Figürlerin asimetrik (bebek figürler arası konumlanma ve bedensel hareketlik eş seviyede gerçekleşmez; mavi pijamalı bebek hem fiziksel hem de bedeni salınım bakımından hakimdir) olarak konumlandıkları; bu nedenle, daha en başından, eşitler arası/yatay denebilecek bir etkileşim içerisinde bulunmaktan uzak oldukları görülür. Bu bağlamda, reklam anlatısıyla temsil edilen ikili ilişki simetrik bir karşılıklılık düzleminde gerçekleştiğini söylemek güçleşir. Mavi pijamasıyla erkek öznelliği ifade eden ve bu anlamda Pater'i hortlatan bebek figür, kendisi de erkek olan dış sesle eşleşerek asal/hâkim konuşmacı rolünü elinde bulundurur. İzleyiciye reklamın niyet ettiği mesajı mavi pijamalı bebek aktarır. Bu şekilde, hem izleyiciler hem de Pembe pijamalı bebek figür iletinin pasif alımlayıcıları/ tüketicileri olarak konumlandırılır. Reklam yüzleri arasında gerçekleşen sınırlı mesaj değiş tokuşu, Pater'in gündelik ilişkiler içerisinde "kadın(1y)la" kurduğu diyaloji yoksunu deneyim kurma davranışını anıştırır. Mavi pijamalı bebeğin vücüda getirdiği Pater, kendisine eşlik eden rol partnerini tüm "sevimliliğiyle" yakasından silkerek, onu Sinpaş GYO'nun konut kampanyası hakkında uyarır (Youtube, 2014). Erkek figürün bu dışavurum biçimi "doğal” bir davranışmış gibi gözükür. Fakat bu, kadın öznelliğinin üzerinde akıp gitmekte olan iktidar kurmaya dönük erkek şiddetinin cici/masumane bir örneği olmanın ötesine geçmez. İki bebeğin sıradan oyun çevrelerinde kurdukları ilişkiyi sergileyen bu temsilin bir geri dönüş hikâyesi olabileceği ilk bakışta akla gelmeyebilir. Fakat saniyelerle sınırlı bu basit filmsel akışta bile Pater' in iş başında olduğu fark edilebilir. Sinpaş GYO reklam filminde maddileşen Pater, gündelik yaşamın güç ilişkileri içerisinde edinemediği hâkim konumu edinerek sağlayacağı kısmi hazzın peşinden koşmuş, bunu yaparken; gerisin geri dönerek varlığını bebek bedeni dolayımıyla ilan etmiştir. Tarihsel belleğin gözden uzak bir köşesinde inzivaya çekilmeyi reddeden Pater görünür olmuş, tıpkı bu çalışmada olduğu gibi kendisinden bir kez daha söz ettirmeyi başarmıştır.

\section{Sonuç}

Tüketici/izleyici öznenin şeylere yönelik arzusunun kültürel içeriklerle inşa edildiği günümüzde; reklam filmleri farkında olduğumuz/olmadığımız eksikliklerimizi bilince çıkararak, yeni ihtiyaçlar yaratır. Reklamlar ihtiyaç ve gereksinimleri manipüle etmekle kalmayıp, bunların giderilmesine dönük reçeteler sunar. Reklamların en iyi yaptığı iş; bu reçeteleri göz gezdirdiğimiz bir kadın dergisinin iç kapağında, sokakta yürürken rastladığımız bir billboard aracılığıyla ya da müptelası olduğumuz bir dizi filmin reklam arasında tüketici/izleyiciye anlatmaktır. Simgesel kodlarla örülü bu metinler öznenin kendinde libidinal enerjisini harekete geçirerek, bireye, içsel güçlerini tüketim nesnelerine yatırması yönünde ikna ve telkinlerde bulunmaktadır. Kendine özgü içsel mantığı ve tüketim edimini yaratma iddiasıyla üretilen ticari mesajları toplumsal bilince taşıyan reklamlar; $n 11$.com reklamı örneğinde görüldüğg̈ gibi gündelik dilin tüm sarihlih ve sahihliğini kendi meta dili içerisine yedirerek modüle eder. Reklam sloganları ve/ya gömülü mesajların çağrıştırdığı yan anlamlar yoluyla, pazarlanan nesne ve hizmetlerin tam ve bütün olduğu imlenir.

Akbank reklam filmi örneğiyle de görüldüğü gibi reklamlar, özneyi haz evrenine taşıdığı iddiası, dili üzerine kurgulanmıştır. Bu manpülatif dil, öznenin satın alma etkinliğiyle tüketim döngüsünü sonlandıracak olan şu ya da bu nesne veya hizmetin etrafinda kuruludur. Çeşitli simge ve mesajlarla olduğu kadar belirli bir yorum bilgisine dayanarak formüle edilen ve izleyi- 
Özcan, E. (2017). Bir Žižekci okuma: n11.com, Akbank \& Sinpaş GYO reklam filmlerinin söylemsel analizi. International Journal of Social Sciences and Education Research, 3(3), 899-913.

ci/tüketicinin dikkatine sunulan bu nesne ve hizmetler; özneye hiç durmaksızın peşinde koştuğu eksiği yeniden hatırlatarak/duyumsatarak, bu eksiği, sunulan ürünleri satın alarak giderebileceği anlatısını işler. Oysa ki bu nesneleri bir kez tüketen özne, asla tam olarak sağlayamacağı tatminini gidermek için daha fazla tüketmek; yeniden ve bir kez daha tüketmek zorunda kalır. Duyumsadığı eksik tatmin olmaktan uzaktır, çünkü reklamlar tüketici/izleyiciye sadece özlem duydukları gerçekliği sunma vaadi taşırlar. Tam da bu nedenle, bireylerin arzularının doyurulmasına değil, şeylere karşı duyulan dürtünün tekrar tekrar üretilmesine hizmet ederler. Buna ek olarak, reklamlar, görsel bir dille hikayeleştirerek dolaşıma soktukları kamusal anlatılarda gerçeği değil, gerçeğin toplumsal düzeyde tasarlandığ fantezilere yer verirler. Bu fanteziler bireylerin içerisinde yaşadıkları toplumsal gerçekliğe dair manipüle edici, yanlış bilinç yaratıcı fakat yine de açıklayıc1/yorumlayıcı yanılsamalardan başka bir şey değildir. Reklam filmlerinin alametifarikası Berger'in de bahsettiği gibi bu fantezilerle uyumlanabiliyor, bireylerin fantezileriyle uyumlu hikayelere yer veriyor oluşunda yatar (2014, s.146). Reklam filmleri Akbank reklam filmi örneğinde gösterilmeye çalışıldığ 1 gibi, özneye farklılığı, ayrıksılığı ve buradan hareketle "ayrıcalığı" deneyimleyebilecekleri bir haz üretim ufku sunar. Bunu yaparken dil, kültür ve psişik belirlenimlerin evreni "Simgesel” düzenin karşımıza çıkarmış olduğu çıkmazları çalımladığı, ya da bu çıkmazları aştığı yanılsamasını yaratırlar. Gelgelelim ki, özne bir yandan imgesel özdeşimleri diğer yandan ise, "ancak ve ancak göz ucuyla görülebilen Gerçek'in tanımsız bulanıklığı” (Žižek, 2013, s.233) arasında hapsolup kalır. Peşisıra gittiği İdeal Ben’i bulma uğruna yeniden ve yeniden tüketir.

Toplumsal söylemin bir parçası olarak simgeselleştirilmiş olanı taşıyan reklamlar, aynı zamanda simgeselleştirilmiş olanın kendisidirler. Reklamlar ideolojik-kültürel evrenselliğin görünümlerinden biri olarak, farklı anlam ve yorumları taşırlar. Bu anlam ve yorumlar farklı söylemlere, ideolojik gösterenlere işaret ederler. Akbank reklam filmi örneğinde de görüldüğü gibi reklamlar aracılığıyla toplumsal alana yayılan "seçme özgürlüğü" benzeri nosyon ve söylemler "Simgesel”e içkin bozucu unsurlarla mürekkeptirler. Fakat bu unsurlar kendisini öylece göstermezler. Bu tikel kırılmaların ortaya çıkarılabilmesi için farklı, yamuk bir bakma eylemi zorunludur. Akbank reklam filminin algı duvarına çarptı̆̆ "seçme ve "tercih özgürlüğü" bu söyleme yamuk bakıldığında, ya da semptomatik bir okuma getirildiğinde antimoniktir; bireyler yapılandırıcı ilke ve standartlar içerisinde tüketmeyi, eskimiş, kullanım ömrünü yitirmiş olanın ne olduğunu; yine, tüketim ömrünü yitireni yenisiyle değiştirmeyi, eski olanın yerini yenisiyle doldurmayı öğreniriz. Diğer yandan, herkes eski olanı yenisiyle tüketerek ikame ederken, bizler de bundan geri kalmanın rahatsızlığını hissederiz. Baskıcı hazzın etkisiyle geri durmaktansa diğerleri gibi tüketmeye ve tüketerek mutlu olmaya yöneliriz. Tam da bu nedenlerle özgürce, hiçbir baskı ya da iç/dış etkiyenin ağırlı̆̆ı, belirlenimi altında kalmaksızın seçim yapamaz, tercihlerde bulunamayız. Bir başka deyişle, seçim özgürlüğü özgürlük değil ama daha çok zorunluluktur; seçmek zorundayızdır. Seçmeden, tercihlerde bulunmadan var olamayız.

Her ne kadar işlevleri gereği tecimsel içerikler olsalar da, reklamlar tıpkı Sinpaş GYO reklam filmi örneğinde gösterildiği gibi içerisinde üretildiği toplumsal gerçekliğin izlerini taşırlar. Reklamlar toplumsal'a yaydıkları mesajlar aracılığıyla sadece belirli bir ürün veya hizmeti tanıtarak, bireyleri o ürün veya hizmeti satın almak yönünde ikna ve telkinde bulunmazlar. Bu içerikler, yansıttıkları toplumsal temsiller yoluyla toplumsal'ın asimetrik, dikey doğasına işaret eder ve toplumsal'ı şekillendiren güç ilişkilerini yeniden üretirler. Simgesel hesabı görülemeyen, simgesel borcu ödenmemiş Pater benzeri asimetri üretici toplumsal yapı/özne ve bunun ifadesi hegemonik tipolojileri reklam filmleri aracıllğıyla hortlamakta, talep ettikleri şeyi yeni- 
Özcan, E. (2017). A Žižekian reading: Discourse analysis of n11.com, Akbank \& Sinpaş GYO advertisements. International Journal of Social Sciences and Education Research, 3(3), 899-913.

den hatırlatmaktadır. Pater Sinpaş GYO reklam filminde görüldüğ̈̈ gibi cici/masumane k1lıklarla karşımıza çıkmış olsa da istediğini alır ve baskılayıcı varlığını bir kez daha hissettirir.

\section{Kaynakça}

Argın, Ş. (1992). "Kapitalist Toplumda İşin ve İşgücünün 'Kaderi': Fordizmden Postfordizme”, Birikim Dergisi, 41, s.16-29.

Baker, U. (2012). "Dolaylı Eylem”, Ege Berensel (der.), İstanbul: Birikim

Berger, J. (2014). “Görme Biçimleri”, Çev. Yurdanur Salman, İstanbul: Metis

Boyle, K. (2008). “The Four Fundamental Concepts of Slavoj Žižek’s Psychoanalytic Marxism”, International Journal of Žižek Studies, 2(1), s. 1-19.

Bourdieu, P. (1995). "Pratik Nedenler: Eylem Kuramı Üzerine”, Çev. Hülya Tufan, İstanbul: Kesit Yayincilik

Bourdieu, P. ve Wacquant, L. J. D. (2003) "Düşünümsel Bir Antropoloji İçin Cevaplar”, Çev. Nazlı Ökten, İstanbul: İletişim

Bursa Modern. (2014). "Reklam Filmleri" (http://sinpasbursamodern.com/BasinReklamFilmleri.aspx adresinden erișilmiștir) 16.06.2014

Cremin, C. (2011). "iKomünizm”, Çev. Aydın Çavdar, İstanbul: Ayrıntı

Dino, F. (2014). "Terms Used by Psychoanalysis", (https://www.cla.purdue.edu/english/theory/psychoanalysis/psychterms.html adresinden erişilmiştir) 06.06 .2014

Evans, D. (1996). “An Introductory A Dictionary of Lacanian Psychoanalysis", London and New York: Routledge

Featherstone, M. (1996). "Postmodernizm ve Tüketim Kültürü”, Çev. Mehmet Küçük, İstanbul: Ayrıntı

Freud, S. (2011). "Metapsikoloji”, Çev. Aziz Yardımlı, İstanbul: İdea

Hall, S. (2003). "Kültür, Medya ve "İdeolojik Etki”, Mehmet Küçük (der.), Çev. Mehmet Küçük, Medya, Íktidar, Ídeoloji içinde, Ankara: Bilim ve Sanat Yayınları

Inglehart, R. F. (2008). “Changing Values Among Western Publics from 1970 to 2006”, West European Politics, 31 (1-2), ss.130-146.

Lacan, J. (1969-1970). “Seminar 1969-1970” (http://www.valas.fr/IMG/pdf/THE-SEMINAR-OFJACQUES-LACAN-XVII 1 envers de la P.pdf adresinden erişilmiştir) 01.12.2014

Lacan, J. (1978). "The Four Fundamental Concepts of Psychoanalysis”, Çev. Alan Sheridan, Paris: Éditions du Seuil

Marcuse, H. (1991). "One-Dimensional Man. Studies In The Ideology of Advanced Industrial Society", Routledge: London and New York

Marx, K. (1998). “Artı-değer Teorileri”, Çev. Yurdakul Fincanc1, Ankara: Sol

Olson, G. A. ve Worsham, L. (2001). "Slavoj Žižek: Philosopher, Cultural Critic, and CyberCommunist", JAC, 21(2), s.251-286.

Oswald, L. (2008), "Psychoanalysis and Advertising: Positioning the Consumer in Advertising Discourse", American Academy of Advertising Conference Proceedings, University of Illinois

Philips, L ve Jorgensen, M. (2002). "Discourse Analysis as Theory and Method", London: Sage

Rigel, N. (2005). "Lacan'ın Çekiciyle Put Kırmak. Slavoj Žižek”, Nurdoğan Rigel vd. (der.), Kadife Karanlık. 21.Yüzyll İletişim Çağını Aydınlatan Kuramcılar içinde, İstanbul: Su

Trehan, M. ve Trehan, R. (2007). "Advertising and Sales Management”, New Delhi: V.K. (India) Enterprises

Tura, S. M. (2010). “Freud'dan Lacan'a Psikanaliz”, İstanbul: Kanat 
Özcan, E. (2017). Bir Žižekci okuma: n11.com, Akbank \& Sinpaş GYO reklam fillmlerinin söylemsel analizi. International Journal of Social Sciences and Education Research, 3(3), 899-913.

Youtube. (2013). “Akbank Neo Kart İkizler”, (http://www.youtube.com/watch?v=ASnGZA498Qs adresinden erişilmiştir) 22.06.2014

Youtube. (2013). "n11.com TV Reklam Filmi”, (https://www.youtube.com/watch?v=GdI8DgjF7Ck adresinden erişilmiştir) 19.06.2014

Youtube. (2013). "Sinpaş'ın 40.yıl Firsatlarıla Son 40 Ev", (https://www.youtube.com/watch?v=ETe55MSpga0 adresinden erișilmiștir) 23.06.2014

Žižek, S. (1989). “The Sublime Object of Ideology”, New York: Verso

Žižek, S. (1991). “The Metastases of Enjoyment. Six Essays on Woman and Causality”, London and New York: Verso

Žižek, S. (2002). “Kırılgan Temas”, Çev. Tuncay Birkan, İstanbul: Metis

Žižek, S. (2004). "From Desire to Drive: Why Lacan Is Not Lacaniano?", (http://zizek.livejournal.com/2266.html adresinden erişilmiștir) 26.06.2014

Žižek, S. (2013). "Yamuk Bakmak Popüler Kültürden Jacques Lacan’a Giriş”, Çev. Tuncay Birkan, İstanbul: Metis 
Özcan, E. (2017). A Žižekian reading: Discourse analysis of n11.com, Akbank \& Sinpaş GYO advertisements. International Journal of Social Sciences and Education Research, 3(3), 899-913.

\section{Extended abstract in English}

Today's consumer societies witness segments of social life have grown compartmentalized, which goes hand in hand with diversification and fragmentation of individual's needs and wants. In an epoach of seemingly undbridled consumerism, we can not therefore reduce people's needs and wants to consumption of material things or services (sustenance, housing, heating and etc.). Though accepting that these needs and wants which are basically identified with industrial societies sitll abide, consumer societies ever-increasingly lean to attain "post-material" needs such as belonging, autonomy, self-expression, aesthetics, intellect, and assuredly the desires. In the course of fragmentation and diversification of humane needs and wants, advertisement media strives to manipulate and direct post material lacks of people. It is apparent that commercial content exponentially targets each and every individual's phantasies, and arouse masses' narsistic wants. In the mean time, it acutely exhibits a bulk of products which tells and reminds us of our lacks. These commodities promise people to attain their desires in exchange for infinite consumption. While this being the case, highly estimated plight diffused by way of advertisements are futile and illusionary. To put it differently, people's desires never quench, and mechanically insist to come back for ever more. Though advertisements reflect us our lacks, or recite "who we actually want to be/should be and what actually we want to have/should have", they are doomed to failure in filling these lacks. Commercial media solely serve to manipulate and reproduce our desires towards consumer products.

In the light of above-mentioned points, the paper attempts to analyse n11.com, Akbank ve Sinpaş GYO advertisements in respect to manipulation of desires. It draws on the Žižekian thought and bolsters its argument basing on the explanatory power of Lacano-Žižekian concepts such as "surplus-enjoyment", "objet petit a", "Symbolic", "jouissance", "looking awry" and "mechanical insistence". It uses Žižekian vocabulary given that it is well-operable in bringing high theory to popular (everyday) culture critique. It also draws on Žižekian thought which is adept to problematise and make visible junction points of psychic processes with macro social phenomena. The paper accordingly aims to analyse and show how advertisements manipulate and arouse our needs and wants. It communicates its readers about ways how these commercial media tell, invoke and promise to deliver our lacks. This work issuing from an inquiry into implicit nature of advertisements is of significance in following ways. First of all, it aims to bring a critique into commercial media and challenge taking-for-granted interpretations of advertisements as sole commercial content. In relation with this, it tends to understand "things" not as meaning-neutral, value-free forms and processes. It thereagainst conceives phenomena as things/processes, which become ascribed value and meaning within social contexts. Unlike a good deal of corresponding study, it adopts a holistic approach by digging into psychic phonemena in its relationality to social processes. In this sense, selected advertisement texts are treated as discoursive forms, and a relevant line of argument are introduced in tandem with Žižekian vocabulary. These discursive content are elicited as social scripts in which apperances of social phenomena is inscribed. While doing an analysis of n11.com, Akbank and Sinpaş GYO advertisements, it is examined that how these specific advertisements become semiotically constructed, and how they are underpinned by a hegemonic narrative. Underlying cultural contexts are critically established and interpreted, in which these meanings become socially produced and reproduced. 